developed; and that a co-operative approach with good international communication and consultation in the region could be most effective.

\section{Cow Green Lost}

Tue battle for Cow Green was finally lost in the House of Lords on February 23, when the Tees Valley and Cleveland Water Bill was given its third reading. This ended what Lord Grenfell described as an exhaustive and somewhat exhausting inquiry into the Bill sponsored by the Water Board and Imperial Chemical Industries, Ltd., seeking to build a reservoir in Upper Teesdale (Nature, 212, 442, 656, and 764; 1966). The committee set up to defend Cow Green, while regretting that it has lost the battle, believes that people are now more aware of the danger to amenity and to botany which schemes of this sort represent. The Defence Committee will now disband, but a wary eye will be kept on developments by a joint working party from the Council for Nature and the Council for the Preservation of Rural England. This group is particularly eoncerned with water resources, and apart from reporting back to its parent bodies it may also publish its findings from time to time.

\section{Navigation on Show}

UNDER the unsuitably melodramatic title of "Man is not Lost" the National Maritime Museum has launched an exhibition to celebrate the bicentenary of the first issue of the Nautical Almanac and Astronomical Ephemerides for 1767. These tables enabled seamen to determine their position at sea accurately by measuring the angular distance of the Moon from certain fixed stars, and until Harrison's chronometer came into widespread use in the 1830s it was the only satisfactory method of determining longitude. Although vitally important in the history of navigation, the Nautical Almanac is not the most interesting subject on which to base an exhibition, and the organizers are to be complimented on the way they have tackled the problem. Choosing to stress the historical importance of the Almanac they have set the exhibition out under the following headings: the founding of the Royal Observatory of Greenwich in 1675; the compilation of the Nautical Almanac by Maskelyne in 1765 and its publication in 1767; the development of the method of position lines for determining latitude and longitude in the mid-nineteenth century; modern methods, which began to be used in 1914, and which included the applications to air navigation in 1937; and astronomical navigation today. The exhibits are all intelligible and well presented, if sometimes incompletely supported by information. The outstanding exhibit is a model which the visitor can operate to measure lunar distances in the same way as they were measured in the past.

\section{Floral Stamps}

Is its choice of designs for the latest set of eight special postage stamps depicting the British flora (on sale on April 24) the Post Office has reached a compromise between the demands of minuscule design and those of botany. The Rev. W. Keble Martin, whose designs for the new $4 d$. stamps were selected, is a keen amateur botanist who has been drawing flowers for sixty years. Mary Grierson, who designed the $9 d$. and 1s. $9 d$. stamps, is the official artist at the Royal Botanic Gardens, Kew.

\section{Sorry, for copyright reasons some images on this page may not be available online}

The artists were asked to submit designs showing familiar members of the British flora. Their final choice was dictated by the need to depict flowers which would be clearly visible against a white background when reduced to the size of a postage stamp. The results are perhaps not every ecologist's dream of a representative selection of the British flora, but hedgerows, woods, fields and waste places -all common British habitats-are well represented, if rather sedately, by twelve familiar flowers. The stamps show flowers rather than whole plants, for extraneous leaves and stems have been eliminated, and this also applies to the names of the plants, omitted for reasons of design and to avoid taxonomic repercussions.

\section{Molecular Weights without Tears}

\section{by a Correspondent in Molecular Biology}

THE development of photoelectric absorption optics for the analytical ultracentrifuge has for the fortunate possessor of such equipment remarkably simplified the problems of molecular weight determination, and makes it possible to perform accurate measurements on unprecedentedly small (microgram) quantities of proteins and other substances. In this system, the ultracentrifuge in effect incorporates a double-beam spectrophotometer, the sample and reference (solvent) being placed in the two compartments of a doublesector centrifuge cell. By scanning the contents of the cell at a wavelength at which the solute absorbs light, the complete concentration distribution can be obtained. At sedimentation equilibrium this leads at once to a molecular weight; the tedious routine of a separate concentration run (which is required by other optical systems that measure only concentration gradients) and dialysis of the solution against solvent are obviated. Moreover, unless the extinction coefficient of the solute is low, the concentration required for the measurements is so small that no extrapolation to infinite dilution is needed, and a single experiment suffices for the determination. This and other benefits accruing from the use of this technique, such as possibilities for the study of ligand binding, have been explored by Schachman and his associates.

In the latest paper in this series, Edelstein and Schachman (J. Biol. Chem.,242, 306; 1967) now describe 